\title{
Transplacental Effects of 3,5-Dimethyl-3'-isopropyl-L-thyronine on Tubulin Content in Fetal Brains in Rats
}

\author{
Tokuyuki TAKAHASHI \\ The 2nd Department of Physiology, Kanazawa Medical University, \\ Kahoku, Ishikawa, 920-02 Japan
}

\begin{abstract}
Summary When 3,5-dimethyl-3'-isopropyl-L-thyronine (DIMIT) (10 ng/ $(\mathrm{g} \cdot$ day)) was administered to pregnant rats, their infants showed signs of hyperthyroidism with suppressed body weight, tachycardia, and tremor at the day of birth. The brain weight did not change but the wet weight of the cerebral cortex was increased in the infants. Tubulin content (per wet weight and per whole tissue) was increased in the cerebral cortex and cerebellum but remained unchanged in the hypothalamus in the DIMITtreated group. DIMIT-induced hyperthyroidism was shown to affect the development of the fetal brain.
\end{abstract}

Key Words: DIMIT, tubulin, development.

Thyroid hormones are now known to be important in brain growth and maturation during neonatal life. Congenital hypothyroidism known as cretinism results in irreversible mental defects if thyroid hormone replacement does not begin shortly after birth. Despite early thyroid hormone replacement, however, such children demonstrate mild developmental defects compared with controls (MACFAUL et al., 1978). Thyroid hormone may be necessary in order to achieve completely normal development not only during neonatal life but also during fetal life. But both $\mathrm{T}_{3}$ and $\mathrm{T}_{4}$ are limited to the transfer across the placental barrier (Dussault et al., 1969; Grumbach and Werner, 1956). For studying the effects of thyroid hormones to the fetus in utero, it would be an advantage to find a thyroid hormone analogue able to cross the placenta.

3, 5-Dimethyl-3'-isopropyl-L-thyronine (DIMIT) has demonstrable thyromimetic activity in many primates (BACHRACH et al., 1983; MELMED et al., 1980; TAMAGNA et al., 1979), and is capable of transplacental movement (COMITE et al., 1978). BACHRACH et al. (1983) have recently demonstrated that the administration of DIMIT to ${ }^{131}$ I-treated mothers prevents the clinical manifestations of cretinism in the fetus using monkeys.

Received for publication December 5, 1983

高橋徳之 
The aims of this preliminary report were to demonstrate whether the administration of DIMIT to pregnant rats could induce hyperthyroidism in the fetus and whether it might have any effects on biochemical signs in fetal nervous cells.

Synthesized DIMIT was kindly provided by Dr. Michael B. Bolger, Ph. D. (University of Southern California).

Eight pregnant rats of Wistar strain were individually maintained in a temperature controlled room $\left(24 \pm 1^{\circ} \mathrm{C}\right)$ and had free access to standard rat chow and water. At day 3 of gestation, 5 rats began to be injected subcutaneously with DIMIT (10 ng/(g body weight - day)) solved in slightly alkaline physiological saline, while another three were given an equivalent volume of the solvent. At the day of birth, the pups were weighed and decapitated. The brains were removed and immediately weighed. On filter paper wet with ice-cold physiological saline, the cerebral cortex, cerebellum, and hypothalamus were separated and rapidly frozen in liquid Freon 12 chilled with liquid nitrogen as previously described (TAKAHASHI et al., 1981). The specimens were kept at $-80^{\circ} \mathrm{C}$ before use. The frozen specimens were quickly weighed and homogenized with an appropriate volume of PMSG buffer containing $0.1 \mathrm{M}$ sodium phosphate, $10 \mathrm{mM} \mathrm{MgCl}_{2}, 0.25 \mathrm{M}$ sucrose, and $0.1 \mathrm{~mm}$ GTP (pH 6.5). Tubulin was assayed using the method of SHERLINE et al. (1974).

At the day of birth, the pups delivered from DIMIT-treated mothers displayed signs of emaciation, tachycardia, and tremor similar to those seen in neonatal hyperthyroidism. The suppressed body weight of the DIMIT-treated pups is shown in Table 1. Although the gain in brain weight of the pups was about the same in both groups, the wet weight of cerebral cortex was significantly increased by the DIMIT-treatment (Table 1).

Tubulin, a subunit of microtubules, is well known to be important for cellular proliferation and maturation (SHELANSKI and FEIT, 1972; BRYAN, 1974). As shown in Table 2, tubulin content (per wet weight of tissue) was significantly increased in the cerebral cortex and cerebellum in the infants delivered from DIMIT-treated mothers. Whole tubulin content (per whole tissue) was also increased in the cerebral cortex and cerebellum following DIMIT-treatment.

Since DIMIT can pass through the placenta to the fetus more easily than $T_{3}$

Table 1. Transplacental effects of DIMIT on the weight of body, brain, cerebrum, cerebellum, and hypothalamus from 1-day-old rats.

\begin{tabular}{lccccc}
\hline & $\begin{array}{c}\text { Body weight } \\
(\mathrm{g})\end{array}$ & $\begin{array}{c}\text { Brain weight } \\
(\mathrm{mg})\end{array}$ & $\begin{array}{c}\text { Cerebrum } \\
(\mathrm{mg})\end{array}$ & $\begin{array}{c}\text { Cerebellum } \\
(\mathrm{mg})\end{array}$ & $\begin{array}{c}\text { Hypothalamus } \\
(\mathrm{mg})\end{array}$ \\
\hline Control & $6.5 \pm 0.1(14)^{\mathrm{a}}$ & $258 \pm 6(6)$ & $135 \pm 6(5)$ & $11.6 \pm 0.5(5)$ & $15.0 \pm 1.6(4)$ \\
DIMIT $^{\mathrm{b}}$ & $5.0 \pm 0.2(23)$ & $265 \pm 2(6)$ & $151 \pm 3(6)$ & $12.9 \pm 0.8(5)$ & $15.7 \pm 0.8(6)$ \\
& $p<0.001^{\mathrm{c}}$ & & $p<0.05$ & & \\
\hline
\end{tabular}

a Mean \pm S.E. (No. of specimens). b Infants born to DIMIT-treated mothers. DIMIT $(10 \mathrm{ng} /(\mathrm{g} \cdot$ day $))$ was administered to pregnant rats from day 3 of gestation to delivery. ' c Student's $t$-test was used for statistical evaluation. 
Table 2. Transplacental effects of DIMIT on tubulin contents in cerebrum, cerebellum, and hypothalamus from 1-day-old rats.

\begin{tabular}{cccc}
\hline & $\begin{array}{c}\text { Cerebrum } \\
(\mu \mathrm{g} / \mathrm{g} \text { wet wt. })\end{array}$ & $\begin{array}{c}\text { Cerebellum } \\
(\mu \mathrm{g} / \mathrm{g} \text { wet wt. })\end{array}$ & $\begin{array}{c}\text { Hypothalamus } \\
(\mu \mathrm{g} / \mathrm{g} \text { wet wt. })\end{array}$ \\
\hline Control & $2,892 \pm 67(4)^{\mathrm{a}}$ & $1,386 \pm 98(5)$ & $2,668 \pm 268(4)$ \\
DIMIT & $3,135 \pm 80(4)$ & $1,714 \pm 90(5)$ & $2,642 \pm 92(6)$ \\
& \multicolumn{1}{c}{$\begin{array}{c}\text { Whole cerebrum } \\
(\mu \mathrm{g})\end{array}$} & Whole cerebellum & Whole hypothalamus \\
& $370 \pm 33(5)$ & $16.0 \pm 1.2(5)$ & $34.0 \pm 6.0(4)$ \\
\hline Control & $463 \pm 23(5)$ & $22.0 \pm 2.0(5)$ & $41.4 \pm 2.6(6)$ \\
DIMIT & $p<0.05$ & $p<0.05$ & \\
\hline
\end{tabular}

a Mean \pm S.E. (No. of specimens). Other details are the same as in Table 1.

or $\mathrm{T}_{4}$, and DIMIT administration to pregnant rats has proved to be 20 times more effective than that of $\mathrm{T}_{4}$ on a molar basis in preventing propylthiouracilinduced fetal goiters without causing maternal hyperthyroidism (COMITE et al., 1978), the administration of DIMIT to normal pregnant mothers probably induces fetal hyperthyroidism in the fetus. Increased tubulin content in the cerebral cortex and hypothalamus at the day of birth in DIMIT-induced hyperthyroid pups suggest that thyroid hormones could exert some effects on developing nervous cells during the fetal life. In our previous studies (TAKAHASHI et al., 1981), we demonstrated that when the neonatal infants were fortified with $T_{3}$ during the first 9 days of life, the infants were induced to neonatal hyperthyroidism and showed some clinical signs and biochemical changes in the nervous system, where the tubulin level (per wet weight) was increased in the cerebellum and hypothalamus but not in the cerebral cortex. The reason for this difference on the tubulin level between the effects of hyperthyroidism in utero and during neonatal life could not be explained at the time but those findings may suggest that the thyroid hormones could be effective at some limited stages in developing nervous cells.

Although the roles of precise thyroid hormone action during the development of central nervous system are still unknown, the hormones should be an important factor achieving completely normal development in the central nervous system.

The author would like to thank Dr. Michael B. Bolger, Ph. D., University of Southern California for the generous gift of DIMIT.

\section{REFERENCES}

Bachrach, L. K., Dibattista, D., Burrow, G. N., and Holland, F. J. (1983) Transplacental effects of 3, 5-dimethyl-3'-isopropyl-L-thyronine on fetal hypothyroidism in primates. Endocrinology, 112: 2021-2024.

BRYAN, J. (1974) Microtubules. Bioscience, 24: 701-711.

Vol. 34, No. 2, 1984 
Comite, F., Burrow, G. N., and Jorgensen, E. C. (1978) Thyroid hormone analogs and fetal goiter. Endocrinology, 102: 1670-1674.

Dussault, J., Row, V. V., Lickrish, G., and VolPe, R. (1969) Studies of serum triiodothyronine concentration in maternal and cord blood: Transfer of triiodothyronine across the human placenta. J. Clin. Endocrinol. Metab., 29: 595-603.

GRUMBACH, M. M. and WeRNER, S. C. (1956) Transfer of thyroid hormone across the human placenta at term. J. Clin. Endocrinol. Metab., 16: 1392-1397.

MacFaul, R., Dorner, S., Brett, E. M., and Grant, D. B. (1978) Neurological abnormalities in patients treated for hypothyroidism from early life. Arch. Dis. Child., 53: 611-619.

Melmed, S., Spira, O., Gordon, A., Gross, J., Jorgensen, E. C., and Hershman, J. M. (1980) Suppression of thyrotropin by 3, 5-dimethyl-3'-isopropyl-L-thyronine in euthyroid and hypothyroid rats. Endocrinology, 107: 1050-1054.

Shelanski, M. L. and FeIt, H. (1972) Filaments and tubules in the nervous system. In: The Structure and Function of the Nervous Tissue, ed. by Bourne, G. H. Academic Press, New York and London, Vol. 6, pp. 47-80.

Sherline, P., Bodwin, C. K., and KipNIs, D. M. (1974) A new colchicine binding assay for tubulin. Anal. Biochem., 62: 400-407.

Takahashi, T., Goto, K., Sudo, S., and Suzuki, M. (1981) Effects of L-triiodothyronine on tubulin content in developing male and female rat brains. Endocrinol. Jpn., 28: 799-808.

Tamagna, E. I., Hershman, J. M., and Jorgensen, E. C. (1979) Thyrotropin suppression by 3, 5-dimethyl-3'-isopropyl-L-thyronine in man. J. Clin. Endocrinol. Metab., 48: 196-200. 